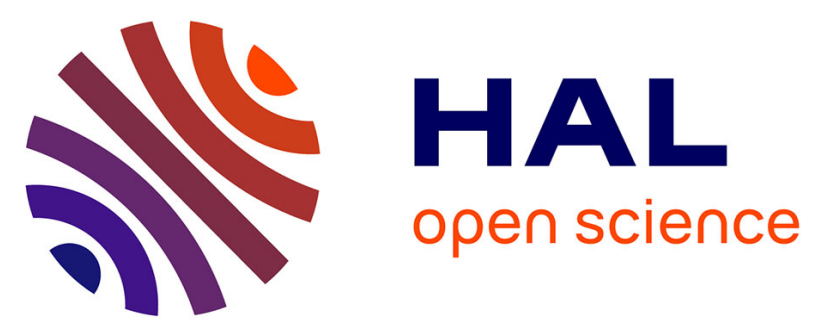

\title{
Development of a chemiluminescent screening assay for detection of vascular endothelial growth factor receptor 1 ligands.
}

Victor Goncalves, Benoit Gautier, Christiane Garbay, Michel Vidal, Nicolas Inguimbert

\section{To cite this version:}

Victor Goncalves, Benoit Gautier, Christiane Garbay, Michel Vidal, Nicolas Inguimbert. Development of a chemiluminescent screening assay for detection of vascular endothelial growth factor receptor 1 ligands.: Chemiluminescent screening assay for VEGF-R1 ligands. Analytical Biochemistry, 2007, 366 (1), pp.108-10. 10.1016/j.ab.2007.03.027 . inserm-00168674

\section{HAL Id: inserm-00168674 https://www.hal.inserm.fr/inserm-00168674}

Submitted on 30 Aug 2007

HAL is a multi-disciplinary open access archive for the deposit and dissemination of scientific research documents, whether they are published or not. The documents may come from teaching and research institutions in France or abroad, or from public or private research centers.
L'archive ouverte pluridisciplinaire HAL, est destinée au dépôt et à la diffusion de documents scientifiques de niveau recherche, publiés ou non, émanant des établissements d'enseignement et de recherche français ou étrangers, des laboratoires publics ou privés. 


\section{Development of a chemiluminescent screening assay for detection of Vascular}

\section{Endothelial Growth Factor Receptor 1 ligands}

Victor Goncalves, Benoit Gautier, Christiane Garbay, Michel Vidal*, Nicolas Inguimbert*

Université Paris Descartes, UFR biomédicale, 45 rue des Saints Pères, Laboratoire de Pharmacochimie Moléculaire et Cellulaire, 75270 Paris cedex 06, France ;

INSERM U648, Paris, 75006, France.

Short title: Chemiluminescent screening assay for VEGF-R1 ligands

*Corresponding authors:

Pr. Michel Vidal

Dr. Nicolas Inguimbert

Université Paris Descartes, UFR biomédicale, 45 rue des Saints Pères, Laboratoire de Pharmacochimie Moléculaire et Cellulaire, 75270 Paris cedex 06, France

E-mail : michel.vidal@univ-paris5.fr; nicolas.inguimbert@univ-paris5.fr

Tel : (33) $142862126 \quad$ Fax: (33) 142864082

Subject category: Enzymatic assays and analyses

List of abbreviations : VEGF, Vascular endothelial growth factor; PlGF, Placenta growth factor; Flt-1, Fms Like Tyrosine 1; KDR, Kinase insert domain receptor; ECD, Extra-cellular domain; VEGF-R, Vascular endothelial growth factor receptor; NP-1, Neuropilin-1; PBS, Phosphate buffered saline; DMSO, Dimethylsulfoxyde; BSA, Bovine serum albumin; Fmoc, 9-Fluorenylmethoxycarbonyle; RLU, Relative light units; btVEGF 165 , Biotinylated VEGF 165 
Angiogenesis is the growth of new blood vessels from a pre-existing vasculature. The deregulation of this physiological process is involved in several pathologies including cancer and inflammatory diseases (atherosclerosis, rheumatoid arthritis or age-related macular degeneration). Consequently, the research for drugs able to disrupt abnormal angiogenesis constitutes an essential research field [1].

Angiogenic sprouting of blood vessels depends on the balance between pro- and antiangiogenic molecules. Among them, the vascular endothelial growth factor (VEGF A) is the major contributor to tumor angiogenesis [2]. The predominant isoform of VEGF A in humans is named $\mathrm{VEGF}_{165}$, according to its length in amino acids. $\mathrm{VEGF}_{165}$ pro-angiogenic activity is mediated through binding to two high-affinity tyrosine kinase receptors: VEGF receptor 1 (VEGF-R1, Flt-1) and VEGF receptor 2 (VEGF-R2, KDR), located predominantly at the surface of endothelial cells but also on several tumour cell lines [3]. Neuropilin-1 (NP-1), a non-tyrosine kinase receptor of $\mathrm{VEGF}_{165}$, acts as a co-receptor, enhancing the activity of VEGF-R2 [4]. The specific role of VEGF-R1 is still a matter of debate. It acts as a negative regulator of angiogenesis during development but an increasing number of papers tend to demonstrate its specific implication as a promoter of angiogenesis under pathological conditions [5].

Considering the central role displayed by the system $\mathrm{VEGF}_{165} / \mathrm{VEGF}-\mathrm{R} 1$ in diseaseassociated angiogenesis, it constitutes an attractive target for the development of antiangiogenic therapies. Among the several strategies developed to disrupt this interaction, a promising approach is constituted by antagonist molecules, with a high affinity for the extracellular domain of the receptor, able to prevent VEGF 165 binding on VEGF-R1 [6].

The affinity of these molecules is commonly evaluated thanks to a radioactive competition test: the tested compound and radiolabeled $\left[{ }^{125} \mathrm{I}_{\mathrm{VEGF}} \mathrm{VEF}_{165}\right.$ are incubated with cells expressing VEGF receptors [7], membranes from endothelial cells [8] or directly with 
recombinant receptors coated on microplates [9], and the remaining activity after washes is measured. Unfortunately, the increasing logistical and regulatory difficulties associated with the use of radioactive isotopes threaten to limit the usefulness of this method. Consequently, the discovery of antagonists is limited by the unavailability of a safe and low-cost highthroughput screening test, and therefore, few antagonists have been reported to date [6]. To help in the discovery of potential new antiangiogenic therapeutics, we have developed a robust non-radioactive assay system for screening of VEGF receptors ligands. Our test is based on competition between compounds and biotinylated $\mathrm{VEGF}_{165}\left(\mathrm{btVEGF}_{165}\right)$, which is detected by chemiluminescence (Fig. 1). This test is performed with the extra-cellular domain (ECD) of recombinant human VEGF-R1, allowing the discovery of receptor-specific molecules. Indeed, cell lines over-expressing one of the receptors proved to be not always a reliable system for testing ligand specificity due to the constitutive co-expression of other receptors, as attested by Perret et al who described for the first time a VEGF-R2 specific antagonist whose biological effect was in fact triggered by interaction with NP-1 [7, 10].

In a first step, we determined the affinity of btVEGF 165 for VEGF-R1 ECD. The surface of white high binding 96-well microplates (Corning Life Sciences, Netherlands) was coated with $100 \mu$ of phosphate buffer saline (PBS; $\mathrm{pH}=7.4$ ) solution containing $200 \mathrm{ng} / \mathrm{mL}$ of VEGF-R1 ECD/Fc chimera (R\&D Systems, UK). The plate was sealed and incubated overnight at $4^{\circ} \mathrm{C}$. After 3 washes with $250 \mu$ of PBS $0.5 \%(\mathrm{v} / \mathrm{v})$ Tween 20 (Buffer A), the plate was blocked by adding $200 \mu \mathrm{l}$ of PBS with $2 \%(\mathrm{w} / \mathrm{v})$ bovine serum albumin fraction IV (BSA; Sigma-Aldrich, France) and agitated at $25^{\circ} \mathrm{C}$ for 2 hours. The plate was washed carefully three times with buffer A. The plates were then ready for sample addition. Alternatively, the plates could be dried under vacuum, sealed with a drying agent and stored at $4^{\circ} \mathrm{C}$ for 1 week. 
Then, $100 \mu \mathrm{l}$ of a solution of btVEGF b $_{165}$ (obtained as part of a Fluorokine biotinylated VEGF kit from R\&D Systems, UK) diluted at varying concentrations in PBS were added to each well. The plate was sealed again and incubated 2,5 hours at $25^{\circ} \mathrm{C}$. Three washes were performed with buffer A and $100 \mu$ of AMDEX $^{\mathrm{TM}}$ streptavidin-horse radish peroxydase (Amersham Biosciences, UK) diluted at 1:8000 in PBS containing 0.5\% (v/v) Tween 20 and $0.3 \%(\mathrm{w} / \mathrm{v}) \mathrm{BSA}$ were added to each well. After $45 \mathrm{~min}$ incubation at $25^{\circ} \mathrm{C}$ under obscurity, the plate was washed 5 times with buffer A and $100 \mu 1$ of SuperSignal west pico chemiluminescent substrate (Pierce, USA) were added. Luminescence was quantified with an

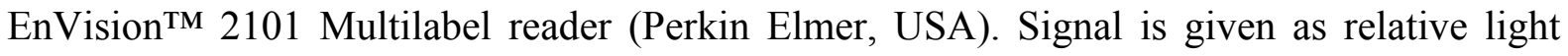
units (RLU). Non-specific binding is defined as the signal measured in the absence of receptor coated on the microplate. The specific binding was calculated as the difference between total binding and non-specific binding. Data were analyzed using the non-linear regression function in Prism ${ }^{\circledR}$ version 4.03 (GraphPad Software, USA).

In a second step, to verify the specificity of the interaction, we realized a competition assay with unlabeled recombinant human $\mathrm{VEGF}_{165}$. The plate was coated with $20 \mathrm{ng} /$ well of VEGF-R1 ECD, then blocked by BSA, and $50 \mu \mathrm{L}$ of $\mathrm{VEGF}_{165}$ (Abcys, France) at various concentrations were added to $50 \mu \mathrm{L}$ of btVEGF $_{165}$ at $5 \mathrm{ng} / \mathrm{mL}(131 \mathrm{pM})$. After $2.5 \mathrm{~h}$ of incubation at $25^{\circ} \mathrm{C}$, wells were washed three times with buffer $\mathrm{A}$ and the btVEGF 165 remaining was detected as previously described. The percentages of displacement were calculated by the following formula: Percentage of displacement $=100 *[1-(\mathrm{S}-\mathrm{NS}) /(\mathrm{MS}-\mathrm{NS})]$, where $\mathrm{S}$ refers to the signal measured, NS is the non specific binding signal and MS is the maximum binding signal obtained with btVEGF 165 without competitor.

The saturation curve is represented in figure $2 \mathrm{~A}$. The binding capacity of btVEGF 165 reached its maximum when added at a concentration of $10 \mathrm{nM}$. Based on three independent experiments, the dissociation constant $\left(\mathrm{K}_{\mathrm{d}}\right)$ was estimated at $750 \mathrm{pM}$, a value comparable to 
the one found by Barleon et al. [11]. Considering that performing the assay with recombinant receptors does not allow to reproduce the favourable effect of membrane microenvironment existing in cell based assays, it is not surprising to obtain a value superior to the $\mathrm{K}_{\mathrm{d}}$ previously described for VEGF 165 interaction with Cos cells transfected with VEGF-R1 (10$30 \mathrm{pM}$ ) [12]. In addition, our competition assay with unlabeled $\mathrm{VEGF}_{165}$ (Fig. 2 B) demonstrates that $50 \%$ of biotinylated ligand binding (introduced at $131 \mathrm{pM}$ ) was inhibited by $387 \pm 60 \mathrm{pM}$ of unlabeled $\mathrm{VEGF}_{165}$. This result proves that the btVEGF 165 exhibits roughly the same affinity for VEGF-R1 ECD as unlabeled VEGF 165 .

Another key point in developing a screening assay is the assessment of its robustness in the presence of dimethylsulfoxyde (DMSO). As a matter of fact, screening of chemical libraries is typically conducted in the presence of low concentrations of DMSO to avoid problems of solubility. We controlled that weak DMSO concentrations $(0.63 \%, 1.25 \%$ and $2.5 \% \mathrm{v} / \mathrm{v}$ ) had no significant effect on btVEGF $_{165}$ binding to VEGF-R1 ECD. The effect was more obvious at $5 \%$ and $10 \%$ DMSO, leading to respectively, $32 \%$ and $46 \%$ decrease of specific binding signals. Nevertheless, the reproducibility of the experiment performed on triplicate wells was not affected in all cases. Based on these data, a final concentration of $1 \%$ DMSO was chosen for development of the assay, allowing the screening of most of chemical compound libraries.

It follows then that this assay represents a strong asset in the search of small-molecule ligands of VEGF-R1. Thus, we verified that molecules exhibiting a weak affinity for the receptor could be readily identified using this screening test. Therefore, we evaluated the affinity of peptides previously described in the literature as ligands of VEGF receptors (Fig. 2 B). Peptides were synthesized by solid phase peptide synthesis on an Applied Biosystems 433A synthesizer (Applied Biosystems, USA) using Fmoc chemistry. They were purified to 
at least $95 \%$ purity by semi-preparative reverse phase HPLC and their identity was confirmed by electron spray MS (LCQ Advantage, Thermo Electron Corporation, USA).

QK (Ac-KLTWQELYQLKYKGI-NH ${ }_{2}$ ) is a VEGF mimicking peptide [8], exhibiting an agonist activity for VEGF receptors. Its affinity was determined by competition with $\left.{ }^{125}{ }^{1}\right] \mathrm{VEGF}_{165}$ for the binding sites of VEGF on cell membranes isolated from bovine aorta endothelial cells which express VEGF-R1, VEGF-R2 and NP-1 receptors. This assay leads to an $\mathrm{IC}_{50}$ estimated in the nanomolar range. Tested on our screening assay, its $\mathrm{IC}_{50}$ for VEGFR1 was measured at $32 \mu \mathrm{M}$. Based on this result, it can be hypothesized that the high affinity of QK for endothelial cells may be triggered essentially by its binding to VEGF-R2/NP-1.

SP5.2 (NGYEIEWYSWVTHGMY-NH ${ }_{2}$ ) has been described as a VEGF-R1 specific antagonist peptide, identified by phage display library screening [13]. To evaluate its affinity for the receptor, El-Mousawi et al. synthesized a fluorescein-labeled SP5.2 peptide and measured the fluorescence signal due to peptide binding to immobilized VEGF-R1/Fc chimera $(1 \mu \mathrm{g} /$ well $)$ in a saturation assay. Based on this experiment, SP5.2 binding was dosedependent, with a half-maximum value at $40 \mu \mathrm{M}$. This in vitro value on purified receptor is in the same order of magnitude than the $\mathrm{IC}_{50}$ obtained for SP5.2 in our chemiluminescent competition assay, measured at $28 \pm 7 \mu \mathrm{M}$.

As a negative control, we chose the peptide A7R (ATWLPPR) initially described as a VEGF-R2 specific antagonist and which recently proved to be a NP-1 specific ligand [7, 10, 14]. As expected, no displacement of tVEGF $_{165}$ was observed in the range of concentrations tested $(3-100 \mu \mathrm{M})$.

Finally, we verified if the screening assay could allow the identification of larger inhibitors of VEGF 165 . Thus, we tested a monoclonal antibody raised again VEGFR-1 ECD (anti-VEGFR-1, clone FLT-19, Sigma-Aldrich). This antibody proved to be able to displace btVEGF $_{165}$ binding to VEGFR-1 with an $\mathrm{IC}_{50}$ of $2.81 \pm 1.59 \mathrm{nM}$ (supplementary data). 
In summary, the current study describes a method for identifying ligands of VEGF receptor 1 based on chemiluminescent detection of biotinylated VEGF $_{165}$ binding to the recombinant receptor. This assay has been developed on an easy to handle 96-well format. Considering the small amounts of proteins used and the suppression of radioactivity issues, this assay represents an interesting progress for the evaluation of new VEGF-R1 ligands and should allow the screening of chemical libraries, even by academic institutions.

\section{References}

[1] P. Carmeliet, Angiogenesis in health and disease, Nat. Med. 9 (2003) 653-660.

[2] N. Ferrara, H.P. Gerber, J. LeCouter, The biology of VEGF and its receptors, Nat. Med. 9 (2003) 669-676.

[3] A.K. Olsson, A. Dimberg, J. Kreuger, L. Claesson-Welsh, VEGF receptor signalling in control of vascular function, Nat. Rev. Mol. Cell. Biol. 7 (2006) 359-371.

[4] N. Guttmann-Raviv, O. Kessler, N. Shraga-Heled, T. Lange, Y. Herzog, G. Neufeld, The neuropilins and their role in tumorigenesis and tumor progression, Cancer Lett. 231 (2006) 1-11.

[5] A. Luttun, M. Autiero, M. Tjwa, P. Carmeliet, Genetic dissection of tumor angiogenesis: are PlGF and VEGFR-1 novel anti-cancer targets?, Biochim. Biophys. Acta 1654 (2004) 79-94.

[6] L.D. D'Andrea, A. Del Gatto, C. Pedone, E. Benedetti, Peptide-based molecules in angiogenesis, Chem. Biol. Drug Des. 67 (2006) 115-126.

[7] R. Binetruy-Tournaire, C. Demangel, B. Malavaud, R. Vassy, S. Rouyre, M. Kraemer, J. Plouet, C. Derbin, G. Perret, J.C. Mazie, Identification of a peptide 
blocking vascular endothelial growth factor (VEGF)-mediated angiogenesis, Embo J. 19 (2000) 1525-1533.

[8] L.D. D'Andrea, G. Iaccarino, R. Fattorusso, D. Sorriento, C. Carannante, D. Capasso, B. Trimarco, C. Pedone, Targeting angiogenesis: structural characterization and biological properties of a de novo engineered VEGF mimicking peptide, Proc. Natl. Acad. Sci. U S A 102 (2005) 14215-14220.

[9] P. An, H. Lei, J. Zhang, S. Song, L. He, G. Jin, X. Liu, J. Wu, L. Meng, M. Liu, C. Shou, Suppression of tumor growth and metastasis by a VEGFR-1 antagonizing peptide identified from a phage display library, Int. J. Cancer 111 (2004) 165-173.

[10] G.Y. Perret, A. Starzec, N. Hauet, J. Vergote, M. Le Pecheur, R. Vassy, G. Leger, K.A. Verbeke, G. Bormans, P. Nicolas, A.M. Verbruggen, J.L. Moretti, In vitro evaluation and biodistribution of a 99mTc-labeled anti-VEGF peptide targeting neuropilin-1, Nucl. Med. Biol. 31 (2004) 575-581.

[11] B. Barleon, F. Totzke, C. Herzog, S. Blanke, E. Kremmer, G. Siemeister, D. Marme, G. Martiny-Baron, Mapping of the sites for ligand binding and receptor dimerization at the extracellular domain of the vascular endothelial growth factor receptor FLT-1, J. Biol. Chem. 272 (1997) 10382-10388.

[12] C. de Vries, J.A. Escobedo, H. Ueno, K. Houck, N. Ferrara, L.T. Williams, The fmslike tyrosine kinase, a receptor for vascular endothelial growth factor, Science 255 (1992) 989-991.

[13] M. El-Mousawi, L. Tchistiakova, L. Yurchenko, G. Pietrzynski, M. Moreno, D. Stanimirovic, D. Ahmad, V. Alakhov, A vascular endothelial growth factor high affinity receptor 1 -specific peptide with antiangiogenic activity identified using a phage display peptide library, J. Biol. Chem. 278 (2003) 46681-46691. 
[14] L. Tirand, C. Frochot, R. Vanderesse, N. Thomas, E. Trinquet, S. Pinel, M.L. Viriot, F. Guillemin, M. Barberi-Heyob, A peptide competing with VEGF165 binding on neuropilin-1 mediates targeting of a chlorin-type photosensitizer and potentiates its photodynamic activity in human endothelial cells, J. Control. Release 111 (2006) 153164.

Fig. 1. Schematic representation of the chemiluminescent screening assay.

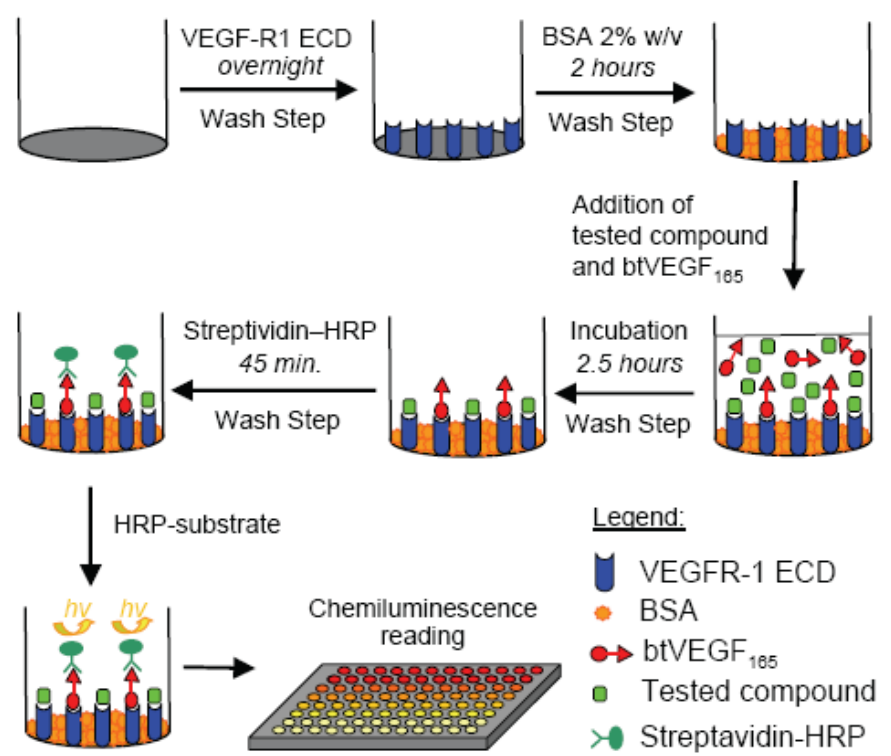

Fig. 2. (A) Solid-phase binding assay of biotinylated VEGF $_{165}$ to recombinant human VEGFR1. Total and non-specific binding curves correspond to the signal observed, respectively in presence $(20 \mathrm{ng} /$ well) or in absence of VEGF-R1. The data show mean numbers from triplicate wells. Error bars represent for standard deviation. (B) Competition assay between human $\operatorname{VEGF}_{165}$ and biotinylated $\operatorname{VEGF}_{165}(5 \mathrm{ng} / \mathrm{mL} ; 131 \mathrm{pM})$ for binding to VEGF-R1 ECD (20 ng/well). Data is presented as a percentage of displacement of biotinylated VEGF $\mathrm{V}_{165}$. (C) 
Competition assay between peptides QK, SP5.2 and A7R and btVEGF ${ }_{165}$ in presence of 1\% DMSO.
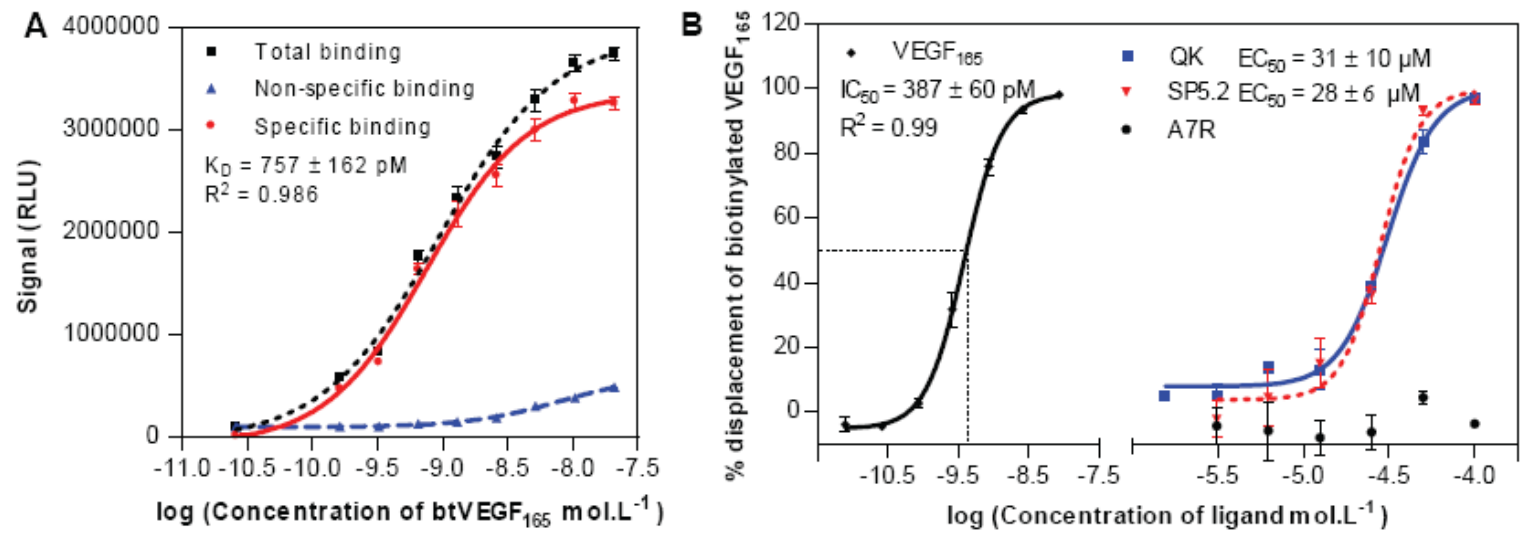